\title{
INDIVIDUAL PAPER PROPOSAL
}

\section{ANNUAL MEETING OF THE AMERICAN POLITICAL SCIENCE ASSOCIATION}

Individual paper proposals are invited from senior scholars, recent Ph.D.s and advanced graduate students. Panels composed of individual papers are organized by the Program Division chairs and will be arranged around common themes. Do not submit a proposal for an individual paper if you are included in a full panel proposal.

\section{Paper Title}

and

Description

IPLEASE PRINT,

TYPE OR

ATTACHI

2. NAME:

ADDRESS:

\section{Present institutional Affiliation:}

4. Ph.D. Degree Received IN 19

From

\section{Audiovisual Equipment Needed}

\section{Poster Presentation: check if preferred}

A poster session is a period of 1 hour and 45 minutes in a room filled with a number of bulletin boards, each big enough for several sheets of typing paper or the equivilent. Presenters put up their materials - a full paper, an outline, tables, graphs, pictures, etc. - and sit next to their posters to talk with interested parties.

7. Multiple SUBMission:

I SENT this PRoposal to the following other division[s] of the Program Committee:
Work PHONE:

Home Phone:

FAX:

E-MAIL: 